\title{
Folklore Reog Ponorogo: Study on Value of Education for the Community
}

\author{
Nugraheni Eko Wardani ${ }^{1}$, Fvaorita Kurwidaria ${ }^{2}$, Kenfitria Dwi Wijayanti ${ }^{3}$, Dewi \\ Pangestu Said ${ }^{4}$, Kundharu Saddhono ${ }^{5}$, Dwi Rahayu Retno Wulan ${ }^{6}$ \\ \{nugraheniekowardani_99@staff.uns.ac.id ${ }^{1}$ \} \\ 1,2,3,4,5,6 Universitas Sebelas Maret Surakarta, Indonesia
}

\begin{abstract}
Reog Ponorogo folklore is closely related to the value of character education. Today in addition to cognitive and psychomotor, character education is a fundamental aspect needed for education in Indonesia. This article aims to examine the values of character education contained in Reog Ponorogo folklore. Reog Ponorogo folklore written by S. Hadi Wirodarsono and published by PT. Kharisma. The method used in this research is content analysis. This article shows that in many Reog Ponorogo folklore once found values of character education. The value there that deserves to be replicated and there is also inappropriate to emulate. Author through descriptions and dialogue capable of presenting data on the value of character education. Expected values of character education in Reog Ponorogo folklore can be integrated in everyday.
\end{abstract}

Keywords: Reog Ponorogo folklore - character education values

\section{INTRODUCTION}

A folklore is essentially an oral story that has long been living and growing in the community. It can be said that folklore is part of the cultural and historical richness of every nation. Folklore spreads and develops orally from one generation to the next in a society [1]. Folklore is a result of literary folk or local society, because it was born among the people, became a legacy of a society, referring to the past, and is part of the community's cultural life.

Folklore is partly a collective culture spreading and inherited from generation to generation among any collective kind traditionally in different versions, either in the form of verbal or examples accompanied by gestures or reminder tools [2]. Folklore is usually passed down orally from one generation to the next. Local wisdom is stored local wisdom locally and culturally, so local wisdom in the folklore can be used as learning for generations. The benefit of the study can be divided into two; theoretically and practically benefit [3]. A similar opinion on the above has also been suggested that the history of folklore studies reveals that folklore in many countries is often inspired by the desire to preserve their national heritage [4].

Folklore is known as a local wisdom in which there is a source of cultural richness that needs to be learned, preserved, and even developed. In folklore it can be showed by the views of life, philosophical value, local wisdom, belief, and politics. In addition it also contains 
experiences, customs, ideals, and other activities that exist in certain area. Therefore, it is closely related to the folklore and the picture of the life of a society in the past. Life of the past has a history of the formation of today's life. Folklore also keeps things in the form of history, sacred places, and relics that must be explored and preserved in order to avoid extinction [5]. So, if the folklore can be explored, preserved, and developed then it will be beneficial to both past and present life. Folklore is able to interpret the balance of social, economic, historical, religious, vocational, and psychological shifts that come together in every literature work [6].

Ponorogo Regency East Java has a very legendary folklore, the origin of Reog Ponorogo. The story is about the struggle of King Kelana Sewandana in overthrowing the cunning King Singa Barong to get his ideal wife, Dewi Sanggalangit. Reog Ponorogo includes legendary stories. The legend is a prose story of people considered by the proponent of the story as something that has really happened. Legend is a story that tells the history of a place or event in the past that tells about a figure, a sacred, and so forth [7].

In today's modernization era, the public appreciation of the folklore is very poor. They tend to be fond of western cultures rather than their own culture. In fact, they now prefer to watch television, movies, and listen to songs via DVD, mobile phones, MP3 or others from reading books about folklore. This is because they have been affected by the rapid development of modern technology. They feel strange about the folklore, not even infrequently many who do not know the folklore does exist in their area. In addition the unbounded present of custom, habits, and ignorance make folklore less desirable. These three things can happen due to lack of knowledge about the roles and significance of folklore for society, especially the young generation.

Nowadays, moral education is indispensable. Character can be interpreted with morals, characters, or behavior [8]. Character is the value of human life that is implemented not just as a habit, but based on understanding and self-awareness to be good person. But in schoollearning, it often only focuses on cognitive and psychomotor aspects. In fact, in the Ministerial Regulation Number 232015 has been regulated on the instilment of moral character. Ironically there are still many schools that have not yet realized the rules.

Character education can be interpreted as an attempt to form the whole person reflected in the words, deeds, attitudes, thoughts, feelings, and works based on the values of religion and the noble norms and morals of Indonesia through guiding, training and teaching activities. The purpose of this is to have a decent heart, well behaved, and maintain morality in carrying out obligations to God and human beings. Good character development prepares someone to become a productive society member with a positive contribution that will affect the change [9]. Thus, it is generally said that the goal of moral education is to form a good person.

Despite having similarities in research on moral education, this study examines the value of the moral education in Reog Ponorogo folklore. Every good literary work, including folklore, always reveals the noble values that are beneficial to its readers. If explored in depth, folklore has an exemplary and wise advice through a character or event, although it is not explicitly communicated. Reader can find the nature of honesty, thoughtfulness, responsibility, cooperation, and so forth in the folklore. This proves that the folklore is closely linked to the value of education, especially the moral education that serves to instill what the student must do and what the student cannot do. Character education not only teaches what is right and wrong to children, but more than that kind of moral education instills decent habits that students must understand, are able to feel, and want to do good deed [10].

The research method used in this research was content analysis. Content analysis is a research method that does not use humans as a research object [11]. In general, content analysis attempts to reveal the various information beyond data presented in the media or 
texts. Thus, content analysis can be defined as the technique of collecting and analyzing the content of a text. The data in this study was obtained through a written source of the object to be studied, namely the Reog Ponorogo folklore by S. Hadi Wirodarsono. The next data in this study was the result of interviews with informants. The technique of collecting data in this research included document analysis, interview, and expert judgment. While the data analysis technique used was data analysis technique namely: (1) data reduction, (2) display data, and (3) conclusions [12].

\section{FOLKLORE REOG PONOROGO}

Birth stories of reog began in 900 years. The story tells about the journey of Kelana Sewandana king who was the king of Bantarangin was looking for his life companion[13]. The king was always accompanied by patih Bujangganong. Finally, the girl who became her wife has been found, Dewi Sanggalangit who was the daughter of King of Kediri. Dewi Sanggalangit gave heavy conditions before he wanted to marry Kelana Sewandana, presenting new art performance in advance. Therefore,reog was created and we can see in the present [14]. In accordance with the above opinion, the dominant figure that appears in Reog Ponorogo folklore is Kelana Sewandana, Dewi Sanggalangit, Singa Barong, King of Kediri, and Bujangganong. So, from time to time folklore in the form of folk story will always exist. But because of the story was in oral, many interpretations occurred though it did not cut part of the story. Furthermore it is stated that from oral tradition, we can see the social reality and mentality of a certain period. Because of the oral tradition contained in the folklore it can be revealed various language creatives to realize the values that exist in a society [15].

The Kelana Sewandana was the youngest and most handsome king of Bantarangin kingdom. He was a powerful and invulnerable king and had a whiplash called Kyai Pecut Samandiman. Kelana Sewandana had a beast-looking governor named Bujangganong. Once, Kelana Sewandana was in love with Dewi Sanggalangit, the princess of the kingdom of Daha (Kediri). So, he sent Bujangganong to propose the beautiful princess.

Dewi Sanggalangit was the daughter of king of Kediri who was famous for her beauty. Propose Dewi Sanggalangit was not as easy as imagined. She asked three conditions, that if a person could fulfill the requirements then she would be queen. The requirement was to bring a handsome young man riding a hundred and forty-four horses, carrying a two-headed animal, and carrying a performance that had never been there until then.

Singa Barong figure in the folklore Reog Ponorogo was often referred to as Singalodra. This figure was said to be the king of the majestic and invulnerable king of Lodaya. But he was stubborn, rude, and his face was described as a tiger. He was also told as one of the king who wanted to marry Dewi Sanggalangit.

The last figure that is often told in Reog Ponorogo folklore is Bujangganong. He was governor of Kelana Sewandana. As a governor he was portrayed as very obedient to the king's orders, even able to bet his life to defend the king and his homeland. In addition, not much told about Bujangganong figures.

\section{EDUCATION VALUE OF BUDI PEKERTI IN FOLKLORE REOG PONOROGO}

Character becomes the controller in life, which means it can be used as a means of sanctifying ourselves from the despicable nature. Character education is also a teaching program in schools that aims to develop the character or habits of students by applying the 
values and beliefs of society as a moral force in his life through honesty, trustworthiness, discipline, and cooperation that emphasize affective domains (feelings and attitudes) without leaving the cognitive realms (rational thinking) and psychomotor realms (skills). Character education can be integrated by the aspect of culture [16]. Therefore, the value that is implied in the character education does not rely solely on knowledge, but it is the act of one who should consider the elements in an integrated way, namely understanding, appreciating and practicing [17]. After emphasizing moral education in affective domain without leaving cognitive and psychomotoric domains students will show enhancement in academic achievement [18].

Folklore Reog Ponorogo has many values of moral education in it. Previous explanations have stated that discretion refers to character, behavior, or habits. Indeed, these characters can be distinguished into two, good characters and bad characters. Of course, we must be smart in sorting and filtering which values are worthy of being modeled and inappropriate to be modeled. So the Ministerial Regulation Number 232015 that regulates the moral character instilment in education will be achieved with maximum result. Because in addition to cognitive and psychomotor aspects affective aspects are essential for every individual.

There are many value of the moral education contained in Reog Ponorogo folklore. These values are of moral education is grouped into four great values, namely attitude toward God, neighbor, self, and the universe [19]. With these four values it will help students to be more devoted to God, to appreciate others, responsible for themselves, and to always keep and preserve the environment. Furthermore it is suggested that these four great values become eight values of moral education, namely: religious, social, gender, democratic, honesty, independence, hard work, and responsibility.

First, folklore Reog Ponorogo contains religious values. The value is reflected in the figure of Dewi Sanggalangit who asked for guidance to God as she was confused to make decision. This is in line with the Javanese saying that Gusti mboten sare (God does not sleep). Dewi Sanggalangit believed that God would surely give way to those who remember Him. The following religious values are contained in Reog Ponorogo folklore.

"Apa sing arep sira tindakake?"

"Dalem badhe nyenyuwun pitedah saking Gusti Ingkang Maha Agung ing sanggar pamelengan.” (p. 24)

'What are you going to do?'

'I will seek guidance from the God in somewhere to be alone.'

Secondly, social value is a value that human beings need to develop in common life, because human is social beings who always needs the help of others. In this research social value is reflected when Goddess Sanggalangit asked Darti's help to pick the jasmine flowers in Tamansari. Then Darti who helped Bibi Wiji to deliver the herbs that would be given to Paman Doblang, a gardener.

Third, gender values are the attitudes and actions that respect the differences between men and women. While in this research can be proven that there is gender equality between men and women in handling the country. The expression that wanita iku mung masak, macak, lan manak is out of date. However, women are also entitled to higher education as well as men.

"Rama, dalem taksih remen sinau, inggih sinau ngelmu agami, ngelmu kanegaran, ngelmu

kawanitan, utawi ngelmu tata krami pasrawunganing ngagesang." (p. 16) 
'Daddy, I still love to study, to learn religion, state, femininity, or social life science.'

Fourth, democratic value is a way of thinking, acting, and behaving that judges the rights and obligations of ourselves and others. In this study, there is a democratic value about accepting defeat and respecting the opinions of others.

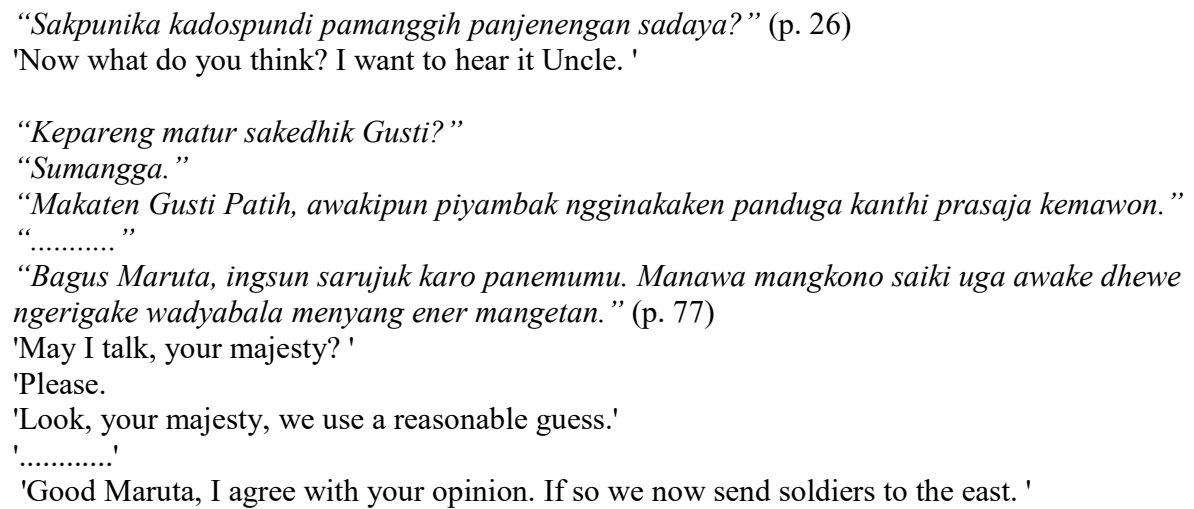

Fifth, the value of honesty is the behavior that is based on efforts to always be trusted in terms of actions, speeches, and jobs. Honesty should be taught to children as early as possible. Reog Ponorogo folklore contains some values of honesty. It appears in Dewi Sanggalangit when she told the story of proposals coming from twenty-five countries to her services.

"Sejatine aku ora arep nyritakake bab iki marang kowe sakloron, amarga sawijining wektu kowe sakarone bakal ngerti dhewe. Nanging becike aku arep nyritakake marang kowe sakloron, supaya kowe bisa krungu kabar iki saka sumbere." (p. 20)

'In fact I do not want to tell you this to you, because someday you two will find out yourself. But it would be better for me to tell you two, so you can hear this news right from the source. '

Sixth, the value of independence is an attitude that is not easy to rely on others in completing a task. The value of independence is seen in King Singa Barong and Prabu Kelana Sewandana. There were times when they had their own independency, without the help of others. They feel that he has been able to do what they think without interfering with others.

"Ora perlu, wadyabala mung arep nyuwen-nyuweni laku."

"Lajeng punapa ingkang badhe katindakakaen Gusti?"

"Ingsun ora butuh kawalan, lan ingsun bakal mangkat dhewe." (p. 87)

'No need to, warriors will only prolong the journey.'

'Then what will majesty do?'

'I do not need control, and I'm going on my own.'

Seventh, the value of hard work is a behavior that demonstrates a sincere effort in coping with various obstacles. Such hard work is characterized by an attitude that is not easy to give up and not easily despair. The hard work value looks in King Kelana Sewandana who could not easily give up in realizing a contest to marry Putri Sanggalangit. Because the Javanese expression states that sapa kang teteken tekun bakal katekan kang dadi tekade is correct, 
whoever is insist in trying on the right path, his desire will be realized. We have to work hard to achieve what we want.

"Ya ingsun mangerti, manawa kita pikir wis cetha manawa sing berjuwang mati-matian ikhtiyar

kanggo minangkani syarat-syarat iku yaiku Prabu Kelana Sewandana." (p. 101)

'Yes, I understand, it is clear that those who fought desperately seek to realize those conditions is King Kelana Sewandana.'

Eighth, the value of responsibility is one's attitude and behavior in carrying out duties and obligations to God, himself, community, environment, and state. A person who is responsible will consciously make a decision and accept the consequences of his decision. It appears to King Kelana Sewandana who had full responsibility for his governors and soldiers. He did not give up on Patih Bujang Ganong who was killed by the devious King Singa Barong. With all his might he destroyed the crimes committed by King Singa Barong. The above is in accordance with the Javanese philosophy known as the Mangkunegaran Trilogy rumangsa melu handarbeni, rumangsa wajib hangrungkebi, mulatsarira hangrasawani.

"Salawase aku ana ing kene, bab iku ora kena kedadeyan. Nyawane patihku luwih pengaji tinimbang nyawane wong sing julig kaya kowe Singabarong." (p. 91)

'As long as I am here, this cannot happen. My life is worth more than a cunning person's life like you, Singabarong. '

\section{CONCLUSION}

Based on the exposure of the values of the moral education in the Reog Ponorogo folklore, it can be concluded that folklore, especially Reog Ponorogo, is a good means to instill values of moral education on children and society. In the Reog Ponorogo folklore, contained noble values can be applied in everyday life. But there are also some worthless values to imitate because it will bring bad character, behavior, or habits. Therefore, in the current era of globalization the value of the moral education in the folklore of Reog Ponorogo is one of the alternatives that need to be instilled and taught. With good character, it will create a society that has tepa slira and always empan papan.

This article recommends further research for other folklore to analyze the value of whatever education it contains. As an Indonesian citizen, we must be proud of the cultural diversity we have. The cultural diversity is a great legacy. All parties must synergize to preserve Javanese culture.

\section{REFERENCES}

[1]. Fang, L.Y. A History of Classical Malay Literature..Jakarta: Yayasan Pustaka Obor Indonesia, 2013

[2]. Sikharulidze, K. "Fairy-Tale as a Genre" on .Journal of Education, Vol.1 No 2, October 2012.

[3]. Saddhono, K; Rakhmawati, A; Hastuti, S. "Indoglish Phenomenon: The Adaptation of English Into Indonesian Culture” .on Ponte. Vol. 72, No 3, December 2016

[4]. Bronner, S. J. The Meaning of Folklore.Logan: Utah State University Press, 2007.

[5]. Leach, M. (ed). "Definitions of Folklore"on .Journal of Folklore Research, Vol. 33, No. 3, July 1996.

[6]. Ivey, B. "Values and Value on Folklore" on.Jurnal of American Folklore, Vol.124 No 491, April 2011. 
[7]. Danandjaja, J. Folklor Indonesia: IlmuGosip, Dongeng, dan lain-lain. Jakarta: PT. Pustaka Utama Grafiti, 1997.

[8]. Brown, E. "No Child Left Behind and the Teaching of Character Education" on .Jurnal $A B N F$, Vol 24No 3, January 2013.

[9]. Sulistyobudi, N. "Seni Karawitan Jawa: Pendidikan Budi Pekerti” on Jurnal Jantra, Vol. [10]. 8 No 1, July 2013

[11]. Kamaruddin, S. "Character Education and Students Social Behavior" on .Journal of Education and Learning. Vol 6 No 4, December 2012.

[12]. Martono, N. Metode Penelitian Kuantitatif: Analisis Isi dan Analisis Data Sekunder. Jakarta: Raja GrafindoPersada, .2011.

[13]. Miles, M. B. \& Huberman, A. Michael. Analisis Data Kualitatif. Jakarta: UI Press, 1994. Wirodarsono, S. H(2000). Reog Ponorogo. Surakarta: Kharisma.2016.

[14]. Conrad, J. A. "The Storied Time of Folklore" on Jurnal Western Folklore, Vol. 73 No 2 February 2014

[15]. Thompson, T \& Paul J.S. "Folklore, Western Folklore, and the Passage of Time: an Editorial Introduction” on Western Folklore Journal, Vol. 75 No2, April 2015

[16]. Benninga, J. S.. "The Relationship of Character Education Implementation and Academic Achievement in Elementary Schools"on Journal of Research in Character, Vol. 15 No. 2, September 2015

[17]. Zuriah, N. Pendidikan Moral \& Budi Pekerti dalam Perspektif Perubahan. Jakarta: Bumi Aksara. 2007.

[18]. Miller, T. W. "Character Education as a Prevention Strategy in School-Related Violence" on .The Journal of Primary Prevention, Vol. 5 No. 4 June 2005. 